\title{
Micropropagation of Artemisia granatensis
}

\section{Margarita Clemente, Pilar Contreras, Juana Susín, and Fernando Pliego-Alfaro ${ }^{1}$ \\ Botanic Garden, University of Córdoba, Apartado 3048, Córdoba 14080, Spain}

Additional index words. tissue culture, germplasm conservation

Artemisia granatensis Boiss. ('Manzanilla Real') is only endemic to the Sierra Nevada in the Province of Granada, Spain (Prieto, 1983; Willkomm and Lange, 1870). The species has been classified as endangered by the International Union for the Conservation of Nature with very little probability of surviving in nature (Gómez-Campo et al., 1988; Sáinz-Ollero and Hernández-Bermejo, 1981; Intl. Union Conservation Nature, 1982) and its removal from nature is forbidden by Spanish and international authorities.

Propagation occurs by seeds, which germinate best in shaded areas (Prieto, 1983). The difficulty of finding specimens for seeds, the impossibility of collecting plants legally, and the urgent need for many individuals for their in situ conservation led us to try tissue culture techniques as a means of propagation.

Stock plants were supplied by the Agricultural Research and Development Center in Lanjarón, Granada, and by the Germplasm Bank of the Polytechnical Univ. of Madrid, Spain. Shoot-tip explants (2 cm long) were surface-sterilized for $10 \mathrm{~min}$ in $0.5 \%$ $\mathrm{NaOCl}$ and two drops of Tween 20 per 100 $\mathrm{ml}$. After removal of several leaves, the explants were immersed again in $0.25 \% \mathrm{NaOCl}$ and rinsed three times in sterile distilled water. The shoot tips were recut to $2 \mathrm{~mm}$ and placed in agar-solidified medium. The basal medium contained MS salts (Murashige and Skoog, 1962), 0.55 mm myo-inositol, 2.9 $\mu \mathrm{M}$ thiamine-HCL, $2.4 \mu \mathrm{M}$ pyridoxine-HCL, $4 \mu \mathrm{M}$ nicotinic acid, $26.6 \mu \mathrm{M}$ glycine, 87.6 mM sucrose, and $0.8 \%$ agar (Difco Bactoagar). Treatments consisted of either $\mathrm{O}, 0.22$, or $0.44 \mu \mathrm{M} \mathrm{N}$-(phenylmethyl) -1H-purine-6amine (BA). The $\mathrm{pH}$ was adjusted to 5.7

\footnotetext{
Received for publication 7 Mar. 1990. This project was funded by the Agricultural Research and Extension Agency and the Environmental Agency of the Andalusian Autonomous Government. The cost of publishing this paper was defrayed in part by the payment of page charges. Under postal regulations, this paper therefore must be hereby marked advertisement solely to indicate this fact.

${ }^{1}$ Agricultural Research and Development Center, Churriana, Málaga, Spain.
}

before autoclaving, and $25 \mathrm{ml}$ of medium was dispensed in each $150 \times 25-\mathrm{mm}$ test tube (Bellco Glass, Vineland, N.J.). Cultures were incubated at $25 \mathrm{C}$ under a radiant flux of $45 \mu \mathrm{mol} \cdot \mathrm{s}^{-1} \cdot \mathrm{m}^{-2}$ supplied by Sylvania Gro-Lux lamps and a 16/8-h light/dark photoperiod. Cultures were transferred to fresh medium every 4 weeks. Primary shoot length and number and length of axillary shoots were recorded at the end of each subculture.

One-centimeter-long microshoots were rooted in test tubes containing $25 \mathrm{ml}$ of basal medium supplemented with either $1 \mathrm{H}$ - indole-3-acetic acid (IAA) (0.57-17 $\mu \mathrm{M}), 1$ naphthaleneacetic acid (NAA) (0.53-16 $\mu \mathrm{M})$, or $1 H$-indole-3-butyric acid (IBA) (0.49-14 $\mu \mathrm{M})$ for 3 days or 4 weeks. Shoots cultured for 3 days were transferred to test tubes containing basal medium without growth regulators for the remainder of the 4-week culture period. Microshoots were also rooted using quick immersion $(5-45 \mathrm{sec})$ in IAA or IBA $[3 \%(\mathrm{w} / \mathrm{v}) 1 \mathrm{~N} \mathrm{KOH}]$ at 10 to $100 \mathrm{mg} \cdot \mathrm{liter}^{-1}$ and then placed in peat in 500-ml glass jars. Microshoots were also placed directly into rooting medium without quick immersion. Glass jar cultures were incubated in a greenhouse at $15-28 \mathrm{C}$. The number of roots were recorded after 4 weeks.

More than $70 \%$ of the shoot tips cultured elongated and were used in the proliferation experiments. Although elongation of the main shoot was greater on medium without BA, the number of axillary shoots increased markedly with BA treatments (Table 1). This difference remained constant throughout the four subcultures.

In our study with A. granatensis, the highest shoot proliferation rate was achieved with $0.44 \mu \mathrm{M}$ BA, although most of the axillary shoots were vitrified by the fourth subculture. No vitrification problems occurred in other Artemisia species (Gautheret et al., 1984); however, they recommend a reduction of BA to $0.04 \mu \mathrm{M}$ to obtain shoots useful for rooting. Similarly, in A. granatensis, a reduction in BA to $0.22 \mu \mathrm{M}$ was necessary to avoid vitrification and to obtain goodquality axillary shoots.

Incorporation of auxins into the basal medium for 3 days did not enhance either the rooting percentage $(70 \%)$ or the number of roots per culture (3.5) relative to those obtained in controls. Also, the presence of IAA during the entire culture period decreased the rooting percentage $(50 \%$ at $0.57 \mu \mathrm{M}$ and $0 \%$ at $17 \mu \mathrm{M}$ ), whereas roots were absent with IBA and NAA at any of the concentrations tested.

More than $50 \%$ of the microshoots developed roots when placed directly into covered glass jars with peat during the first week of culture, after which the lids were removed. After 4 to 5 weeks, plants with well-developed root systems were transferred to pots $(500 \mathrm{ml})$ containing peat. This proved to be the best procedure for the acclimatization of the plantlets. Brief immersion of microshoots in 10 to $100 \mathrm{mg}$ IBA or MA/liter did not enhance rooting.

Satisfactory micropropagation of A. granatensis can be accomplished. Several hundred plants have been successfully acclimated using this method and are thriving and flowering in the Córdoba Botanic Garden, Spain.

\section{Literature Cited}

Gautheret, R., C. Leddet, and C. Paupardin. 1984. Génétique, sélection multiplication. ISur l'amelioration de génépis (Artemisia umbelliformis et A. genipi) par culture de méristemes. Centro Recherche Acad. Agr. de France 70, 10:1237-1246.

Gómez-Campo, C. et al. 1988. Libro rojo de especies amenazadas de España Peninsular e Islas Baleares. Ministerio de Agricultural y Pesca. Inst. de Conservación de la Naturaleza Serie Técnica Press, Madrid.

International Union for the Conservation of $\mathrm{Na}$ ture. 1982. List of rare, threatened and endemic plants for the countries of Europe. Intl. Union Conservation Nature Threatened Plants Comm., Kew, U.K.

Murashige, T. and F. Skoog. 1962. A revised medium for rapid growth and bioassays with tobacco tissue cultures. Physiol. Plant. 15:473497

Prieto, P. 1983. Flora de la tundra de Sierra Nevada. 2nd ed. Univ. Granada Press, Granada.

Sáinz-Ollero, H. and J.E. Hernández-Bermejo. 1981. Síntesis corológica de las dicotiledóneas endémicas de la Peninsula Ibérica e Islas Baleares. Monografías Inst. National de Investigaciones Agrarias, Madrid.

Willkomm, M. and J. Lange. 1870. Prodromus Florae Hispanicae. vol II. ed. E. Schweizerbart'sche Verlagsbuchhandlung, Stuttgart.

Table 1. Response of Antemisia granatensis shoottip explants to BA. ${ }^{2}$

\begin{tabular}{|c|c|c|c|}
\hline \multirow[b]{2}{*}{$\begin{array}{l}\mathrm{BA} \\
(\mu \mathrm{M})\end{array}$} & \multirow{2}{*}{$\begin{array}{l}\text { Length } \\
\text { main shoot } \\
(\mathrm{cm})\end{array}$} & \multicolumn{2}{|c|}{ Axillary shoots } \\
\hline & & No. & $\begin{array}{l}\text { Length } \\
(\mathrm{cm})\end{array}$ \\
\hline 0 & $2.1 \pm 0.1$ & $0.2 \pm 0.1$ & $0.7 \pm 0.1$ \\
\hline 0.22 & $1.5 \pm 0.0$ & $8.2 \pm 0.4$ & $1.0 \pm 0.0$ \\
\hline 0.44 & $1.2 \pm 0.0$ & $13.8 \pm 0.3$ & $0.5 \pm 0.0$ \\
\hline
\end{tabular}

${ }^{z}$ Means $\pm S E, 95 \%$ confidence interval for third subculture. 